\title{
Implementasi Teknologi Informasi di Bidang Kesehatan
}

\section{Erwan Suganda Putra1}

${ }^{1}$ Faculty Of Computer Universitas Mitra Indonesia

erwansuganda.student@umitra.ac.id

\section{PENDAHULUAN}

Pendekatan Keilmuan Computer Science menjadi rujukan dalam implementasi Produk Teknologi. Penerapan Sistem Informasi menjadi hal yang sangat fundamental (Febriani \& Putra, 2013) . Penggunaan penerapan teknologi dimasa sekarang dan masa mendatang menjadi hal yang sangat penting dalam perkembangan intelegensia Technology (Putra \& Febriani, 2017). Produksi aplikasi berbasis Humanity membuat aplikasi berkembang dengan sangat cepat, sisi efektifitas dan sisi efisiensi menjadi hal yang sangat berperan dalam perkembangan teknologi tersebut (Putra et al., 2018). Sehingga factor dalam pencarian keterbaruan ataupun novelty menjadi hal yang harus dikembangkan diberbagai lini (Putra et al., n.d.).

\section{PERTANYAAN-001}

Berisi deskripsi tentang pertanyaan yang dilontarkan oleh Bpk. Dr. ( c ) Arie Setya Putra, CA, S.Kom, M.T.I ; Menurut anda apakah Infrastruktur Teknologi Informasi menjadi kebutuhan Penting dalam Perusahaan Khususnya Bidang Kesehatan, Berikan Contoh Detailnya? 


\section{HASIL JAWABAN}

Jabarkan Jawaban Anda :

Kebutuhan teknologi di bidang kesehatan sangat lah penting terutama di bidang admisterasi sehingga para pengawai tidak repot - repot lagi untuk mengecek keuangan yang ada di rumah sakit dan ketika ada pasein yang belum bayar atau pun sudah bayar dapat mengeceknya di komputer bagian administrasi,misalnya kita akan mengecek data - data pasien,stok obat,dan data - data lainya yang di miliki oleh rumah sakit tersebut.dengan adanya komputer dan sistem - sistem yang canggih di dalamnya sangat mempermudahkan kita untuk mengeceknya.

Contohnya : komputer untuk melihat data - data yang ada di admisterasi dan untuk mempermudahkan pencarian data - data yang akan di cari atau yang akan digunakan,cctv untuk memantau aktifitas atau pergerakan yang ada di rumah sakit.

\section{DAFTAR REFERENSI}

Febriani, O., \& Putra, A. (2013). Sistem Informasi Monitoring Inventori Barang Pada Balai Riset Standardisasi Industri Bandar Lampung. Jurnal Informatika Darmajaya, 13(1), 90-98.

Putra, A. S., \& Febriani, O. M. (2017). Knowledge Management Online Application in PDAM Lampung Province. International Conference on Information Technology and Business (ICITB), 1, 181-187.

Putra, A. S., Febriani, O. M., \& Bachry, B. (2018). Implementasi Genetic Fuzzy System Untuk Mengidentifikasi Hasil Curian Kendaraan Bermotor Di Polda Lampung. SIMADA (Jurnal Sistem Informasi Dan Manajemen Basis Data), 1(1), 21-30.

Putra, A. S., Sukri, H., \& Zuhri, K. (n.d.). Sistem Monitoring Realtime Jaringan Irigasi Desa (JIDES) Dengan Konsep Jaringan Sensor Nirkabel. IJEIS (Indonesian Journal of Electronics and Instrumentation Systems), 8(2), 221-232. 